\title{
Dairy crossbreeding alternatives to improve New Zealand beef production
}

\author{
S.T. MORRIS'. W.J. PARKER ${ }^{2}$, R.W. PURCHAS', and S.N. McCUTCHEON' \\ 'Animal Science Department, Massey University \\ ${ }^{2}$ Agricultural and Horticultural Systems Management Department, Massey University
}

\begin{abstract}
Beef production in New Zealand could be increased by developing farming systems that profitably utilised heifer and bull calves which would otherwise be slaughtered soon after birth. Evaluation of a once-bred heifer cattle policy over 3 years at Massey University showed that target weights to achieve acceptable calving percentages and final carcass weights can be achieved under pasture feeding. Piedmontese and Belgian Blue sires used over Friesian cows produced bull calves that did not grow significantly faster than straight Friesian animals, but had higher dressing out (57.8 $\underline{\mathbf{v}} 56.7$ v 54.0, $\mathrm{P}<0.05)$ and meat yield percentages (76.0 v 75.7 v 73.2 for Piedmontese, Belgian Blue and Fñ̈siản, respectively). Both the once-bred heifer and the exotic $\mathrm{x}$ bull beef production systems earned greater returns than traditional beef cattle policies at 1992 costs and prices, and could be easily implemented by New Zealand beef producers.
\end{abstract}

Keywords dairy beef, exotic sires, once-bred heifer

\section{Introduction}

Cattle originating from the dairy herd currently contribute approximately 350,000 cull cows, 500,000 bulls and a small number of beef $\mathrm{x}$ dairy heifers to New Zealand beef production. In addition around 800.000 calves are slaughtered annually as 'bobby' veal. The latter industry, which is unique to New Zealand,contributes to $25 \%$ of the annual cattle kill but to less than $3 \%$ of the total beef and veal produced. Beef production could be increased by developing profitable production systems to utilise "non-replacement" heifercalves and by encouraging dairy farmers to increase the use of selected beef breed sires. This paper reports on two research projects that aimed to increase beef production through the retention of surplus dairy calves.

\section{Experimental}

Once-bred heifer systems

The once-bred heifer $(\mathrm{OBH})$ system involves the purchase of heifers (dairy or beef type at4 days to 15 months of age) for heifer beef production (Morris et al. 1991). The heifers are mated at 15 months of age to a beef breed sire. They are sold prior to the eruption of their fourth pair of permanent incisor teeth (which typically occurs at 37 months but may be as early as 30 months of age) so that carcasses are classified as 'heifer,' which normally provides a higher return than cow beef. The progeny of the heifer can either be sold as weaners or retained for finishing.

Evaluation of the OBH system for New Zealand pastoral conditions commenced at Massey University's Ruminant Research Unit in 1989 with the purchase of 50 Hereford x Friesian (HxF) heifers at 14 months of age (255 kg liveweight (LW)) and the same number of 4 month old $\mathrm{HxF}$ calves (120 kg LW). The following year $25 \mathrm{HxF}$ and 25 Simmental x Friesian (SxF) 4 month old calves were purchased at $103 \mathrm{~kg}$ and $111 \mathrm{~kg}$ average $\mathrm{LW}$, respectively. The programme continued in 1991 with the purchase of 25 Hereford x Jersey $(\mathrm{HxJ})$ and $25 \mathrm{HxF}$ calves at 4 days of age. The objectives of the research programme are to develop the management system required to achieve specified target liveweights under pasture feeding (Figure 1) and to evaluate the suitability of different dairy heifer crosses for $\mathrm{OBH}$ beef production

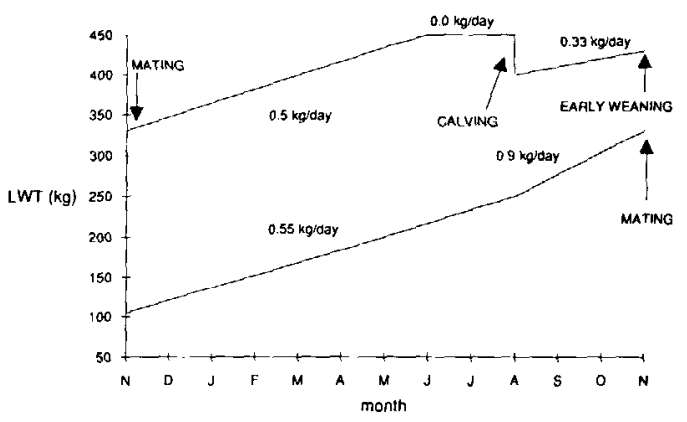

Figure 1 Liveweightgain profile to achieve target weights in a once-bred heifer beef production system. 
Liveweights of all animals wererecorded at monthly intervals and, at slaughter, carcass weight information, including meat composition data, were obtained. At 15 months of age heifers randomly selected for the $\mathrm{OBH}$ system were inseminated to terminal sires selected for ease of calving and meat production using the New Zealand Dairy Board "Genomate" synchronisation programme to terminal sires selected for ease of calving and meat production (Jellie 1991). Breeds of sires used include Charolais and Limousin, and Angus in 1988, and 1989 and 1990 respectively. In 1988 a comparison was made between mated and non-mated heifers for liveweight gain, carcass weight and financial returns, while in 1989 the comparison was made between early weaned (day 90 of lactation) and late weaned (150 days) heifers in a once-bred systen.

\section{Heavily muscled exotic cross bull beef production}

The introduction into New Zealand of the double-muscled or heavily muscled breeds (Piedmontese and Belgian Blue) has increased the choice of beef terminal sires available to farmers. However, little is known about how these breeds perform under New Zealand pastoral conditions. Traditionally, farmers have used Friesians for the production of lean manufacturing beef but the heavily-muscled breeds may also be well-suited to this role.

The liveweight gains of Friesian (F), Piedmontese $x$ Friesian (PxF) and Belgian Blue $x$ Friesian (BBxF) ( $n=30 /$ group) bulls were recorded from arrival at the Massey University Tuapaka Bull Beef Unit at 4 months of age (November 1990) until their slaughter at 15-20 months. The bulls were farmed under the management system described by McRae (1987). except for a 6 week period when a sub-sample of 10 bulls from each breed/ cross were grazed separately to record grazing behavjour and herbage intake as reported by Morris et al. (1992). The bulls were weighed at approximately monthly intervals until the time of slaughter. Liveweights were recorded off pasture prior to trucking the day before slaughter. Groups of 30 animals $(\mathrm{n}=10 \mathrm{per}$ breed/cross) were slaughtered on three separate occasions (corresponding to 17.18 and 20 months of age). Individual hot carcass weights, from which the dressing outpercentage of the bulls was calculated, were recorded at the export abattoir of Weddel-Feildiig Ltd. The total weight of

Table 1 Performance of dairy beef heifer in a mce-bred heifers beef production system.

\begin{tabular}{|c|c|c|c|c|c|c|}
\hline & \multicolumn{6}{|c|}{ Yeac of trial commencement } \\
\hline & \multicolumn{2}{|c|}{1966} & \multicolumn{2}{|c|}{1989} & \multicolumn{2}{|c|}{1990} \\
\hline & Mated & Non-mated & $\begin{array}{c}\text { Early } \\
\text { weaned }\end{array}$ & $\begin{array}{l}\text { Normal } \\
\text { weaned }\end{array}$ & & \\
\hline Breed cross & $H \times F^{1}$ & $H \times F$ & $H \times F$ & $H \times F$ & $H \times F$ & SXF \\
\hline \multicolumn{7}{|l|}{ Liveweight (kg) } \\
\hline $\begin{array}{l}\text {-weaner calf }(4 \mathrm{mo}) \\
\text { mating }(15 \mathrm{mo}) \\
\text {. two year (24 ma) } \\
\text { - pre-slaughter } \\
\text { (c.30 mo) }\end{array}$ & $\begin{array}{l}267 \\
427 \\
435\end{array}$ & 466 & $\begin{array}{l}120 \\
330 \\
450 \\
408\end{array}$ & $\begin{array}{l}120 \\
330 \\
450 \\
459\end{array}$ & $\begin{array}{l}103 \\
326\end{array}$ & $\begin{array}{l}111 \\
342\end{array}$ \\
\hline $\begin{array}{l}\text { Carcass weight }(\mathrm{kg}) \\
\text { - dressing out }\end{array}$ & $\begin{array}{c}211 \\
51.1\end{array}$ & $\begin{array}{r}240 \\
48.9\end{array}$ & $\begin{array}{l}244 \\
50.1\end{array}$ & $\begin{array}{r}220 \\
47.9\end{array}$ & & \\
\hline Caking \% & 60 & & 69 & 69 & & \\
\hline $\begin{array}{l}\text { Calt weaning } \\
\text { weight }(\mathrm{kg})\end{array}$ & 207 & & 175 & 208 & & \\
\hline Financial $\quad(\$)$ & & & & & & \\
\hline $\begin{array}{l}\text { - purchase price } \\
\text { - heifer meat value } \\
\text {-weaner calf }\end{array}$ & $\begin{array}{l}420 \\
542 \\
405\end{array}$ & $\begin{array}{l}420 \\
561\end{array}$ & $\begin{array}{l}270 \\
634 \\
350\end{array}$ & $\begin{array}{l}270 \\
572 \\
416\end{array}$ & 270 & 330 \\
\hline
\end{tabular}

${ }^{1} \mathrm{H} \times \mathbf{F}=$ Hereford $\times$ Friesian, $S \times F=$ Simmental $\times$ Friesian. 
trimmed boneless meat from each sub-group of 10 bulls was recorded, and from this value the average meat yield was estimated for each breed/cross.

\section{Results and discussion}

\section{Once-bred heifer beef production}

Liveweights from weaning to slaughter, and the productivity of the dairy cross heifers used in the $\mathrm{OBH}$ experiments are summarised in Table 1.

The liveweights achieved over the three years of the trial with the different groups of heifers indicate that the target mating weight of $330 \mathrm{~kg}$ can be realised under pasture conditions (Fig.1). To achieve this heifers need to average $0.55 \mathrm{~kg} /$ day from December to August and $0.9 \mathrm{~kg} /$ day from August until mating in November. Feeding to achieve $0.5 \mathrm{~kg}$ liveweight gain per day has been continued until the eighth month of gestation when allowances have been reduced to a maintenance level until calving. Carcass weights of the heifers haveranged from $211-244 \mathrm{~kg}$ at 32 months of age, with dressing out percentages being lower in once-calved than nevercalved heifers, and higher in early weaned than late weaned heifers.

The low calving percentage from the 1988-bom heifers reflects the use of only one cycle of artificial insemination, and in the 1989-bom heifers there was a relatively high calf mortality rate of $20 \%$ due primarily to dystocia. Only two heifers have died from problems associated with dystocia since the research programme commenced. Calf birth weights averaged $37-42 \mathrm{~kg}$ across years and sire breeds. The incidence of dystocia was not influenced by the breed of sire. The levels of dystocia are unacceptable and investigations are currently being undertaken to minimise the problem viamanipulation of early- and mid-pregnancy feeding. Dystocia problems in OBH's were also recorded under UK conditions by Lowman (1987). who subsequently adopted induction of calving to alleviate calving difficulties. Induction cost about $\$ 25 /$ cow in 1992 . This added expense is unlikely to be acceptable to most New Zealand beef cattle farmers.

Early weaning has improved heifer growth rates and hence carcass weight, but at the expense of calf liveweight gain (Khadem et al. 1993). However, this practice offers increased flexibility for selling both the heifer and the weaned calf if pasture supplies diminish over the summer months.

\section{Exotic cross bull beef production}

Liveweights, average rates of liveweight gain, carcass weights and meat yields of the three bull breed/cross are presented in Table 2 .
Table 2 Liveweight, average daily gain (ADG), and carcass dat for Friesian (F), Belgian Blue $X$ Friesian (BB $\times F$ ) and Piedmontese $X$ Friesian (P X F) bulls

\begin{tabular}{|c|c|c|c|}
\hline Parameter & $\mathrm{F}$ & $\frac{\text { Bread }}{B B \times F}$ & PXF \\
\hline \multicolumn{4}{|l|}{ Liveweight (kg) } \\
\hline - at arrival (4 mo) & 127 & 130 & 125 \\
\hline -yearling (12 mo) & 334 & 333 & 323 \\
\hline $\begin{array}{l}\text { - } 15 \text { mo } \\
\text { Slaughter }\end{array}$ & 458 & 457 & 449 \\
\hline Group1-17mo & 504 & 521 & 489 \\
\hline Group 2 - 18 mo & 488 & 477 & 493 \\
\hline Group 3 . 20 mo & 803 & 800 & 585 \\
\hline$A D G(\mathrm{~kg} / \mathrm{d})$ & 0.971 & 0.960 & 0.943 \\
\hline $\begin{array}{l}\text { Carcass weight }(\mathrm{kg}) \\
\text { - dressing-out }(\%) \\
\text { - carcass meat yield }(\%)\end{array}$ & $\begin{array}{l}285 \\
54.0 \\
73.2\end{array}$ & $\begin{array}{l}303 \\
\mathbf{5 6 . 7 0} \\
75.7\end{array}$ & $\begin{array}{l}298 \\
57.8^{b} \\
78.0\end{array}$ \\
\hline
\end{tabular}

abDifferent superscript letters in the same row are significantly different at $\mathbf{P}<0.05$.

Mean data for 10 animals/breed cross.

There were no differences in liveweight gain between F, PxF or BBxF bulls from purchase to slaughter. The liveweight gain of $0.97 \mathrm{~kg} /$ day for Friesian bulls from 4 months . 17 months is high by New Zealand pastoral standards (Nicol 1990) and equates to $621 \mathrm{~kg}$ net carcass weight gain/ha for the Tuapaka stocking rate of 2.8 bulls/ha. Mean carcass weights $(296 \mathrm{~kg})$ did not differ significantly between the breed/cross groups, but the mean weight-adjusted dressing-out percentage was significantly $(\mathbf{P}<0.05)$ higher for the PxF $(57.8 \%)$ and BBxF (56.7\%) bulls than for the F bulls (54.0\%). Total trimmed meat yield as a percentage of carcass weight was also higher for the PxF and BBxF than the F group. The $\mathrm{F}$ bulls also had longer carcasses, lower muscularity scores and meat to bone ratios of the proximal hind leg, slightly more fat cover and more kidney fat. Meat colour and ultimate meat $\mathrm{pH}$ wereunaffected by breed (Purchas et al. 1992).

\section{Financial evaluation}

The respective gross margins $(\mathrm{GM})$ for $\mathrm{OBH}$, exotic $\mathrm{x}$ bull cross and traditional heifer and bull beef cattle policies at 1992 costs and prices are shown in Table 3. The GMs are shown after deducting the opportunity cost of capital - this expense accounts for differences between policies in the amount of capital invested in livestock. Highest returns were easily achieved by bull beef policies and. in the case of exotic $\mathrm{x}$ bulls, these would have been improved (by $\$ 17 /$ bull in the example) if their $2.65 \%$ higher meat yield had been fully rewarded in the beef schedule (McRae 1992). This indicates that 
Table3 Gross margins (1992 costs and prices) for altemative beef cattle production systems. Each stock policy is based on a status quo stock reconciliation, and interest on livestock capital is charged at $12 \%$ p.a.

\begin{tabular}{|c|c|c|c|}
\hline Beef cattle policy & $\begin{array}{c}\text { Carcass } \\
\text { weight } \\
(\mathrm{kg})\end{array}$ & $\begin{array}{c}\text { Sale less } \\
\text { purchase } \\
(\$ / h d)\end{array}$ & $\begin{array}{l}\text { Gross } \\
\text { Margin } \\
\text { (\$/su) }\end{array}$ \\
\hline Once-bred helfer' & 220 & $233+0.6$ calf 3 & 9 \\
\hline Traditional beef helfer ${ }^{2}$ & 200 & 220 & 94 \\
\hline Breeding $\boldsymbol{c o w s}^{\mathbf{3}}$ & 250 & $\cdot$ & 31 \\
\hline Exotic $x$ bull.t & 250 & 362 & 73 \\
\hline Friesian bulls & 250 & 345 & 69 \\
\hline
\end{tabular}

'Purchase of 4 mo calves at $\$ 300 / \mathrm{hd}, 60 \%$ calf survival to sale. ${ }^{2}$ Angus weaner purchased at $8 \mathrm{mo}$ for $\$ 300 / \mathrm{hd}$.

Calving at $27 \mathrm{mo} .65 \%$ calf survival to weaning, sale surplus weaners.

'Purchase 4 mo calves at $\$ 300 / \mathrm{hd}(100 \mathrm{~kg} \mathrm{LW}$, sale at 18-24 mo, $\$ 2.56$ schedule.

Includes adjustment In schedule value for $2.65 \%$ Improvement in meat yield.

only a small premium can be paid on exotic sired dairy bull calves if they can only be grown as rapidly as straight Friesians. Once-bred heifer returns are sensitive to the calving percentage and final slaughter weights achieved (Parker 1991). but, even at 60\% calf survival to sale, returns exceed those of the traditional heifer beef policy. In addition, the $\mathrm{OBH}$ option provides farmers with more alternatives including the sale of proven heifers for use in beef cow breeding herds.

\section{Conclusion}

The reported research with dairy-type cattle at Massey University has demonstrated the potential of these animals for beef production, and adds toreportsofprevious work on the use of dairy-type cattle as beef cows (Hight 1969; Baker et al. 1981) and for bull beef production (McRae 1987). McRae (1992) suggested that the profitability of straight Friesian bull beef policies is likely to decrease in the future as the demand for replacements exceeds the dairy industry supply. The availability of dairy calves to sheep and cattle farmers can be increased by using beef sires, such as the heavily muscled breeds, over a larger proportion of non-Friesian dairy cows or, as is more likely, adopting new cattle policies (e.g. $\mathrm{OBH}$ ) which utilise calves previously slaughtered at four days of age.

\section{ACKNOWLEDGEMENTS}

We thank Mr T G Harvey and Mr K Kilminster (Ruminant Research Unit) and Mr T A Jones (Tuapaka Bull Beef Unit) for their assistance in managing the experimental animals. The once-bred heifer research pro- gramme is funded by the C. Alma Baker Trust and the Livestock Improvement Corporation and the exotic bull beef programme was jointly funded by Agri Ventures NZ Ltd and the New Zealand Belgian Blue Cattle Society.

\section{REFERENCES}

Baker, R.L.; Carter, A.H.; Muller. J.P. 1981. Performance of crossbred cows in the Ruakura beef breed evaluation trial. Proceedings of the New Zealand Society of Animal Production 41 : 254-266.

Hight, G.K. 1969. Friesians on hill country. Sheepfarming Annual : 127-146.

Jellie. H. 1991. Mating management of once-bred heifers. Proceedings of the Once-Bred Heifer Field Day, Massey University : 23-25.

Khadem. A.A.; Morris, S.T.; Parker, W.J.; Purchas, R.W.; McCutcheon, S.N. 1993. Development and evaluation of a once-bred heifer beef production system. Proceedings of the XVII International Grassland Congress (in press).

Lowman, B.A. 1987. Once-bred heifers for beef production In Efficient beef production from grass, ed. $\mathrm{J}$. Frame, British Grassland Society Occasional Symposium No. 22 : 87-96.

McRae,A.F. 1987. Tuapaka beef unit - seasons three and four (and a new direction). Tuapaka Farm Series No. 4, Massey University : 52 pp.

McRae. A.F. 1992. The place of exotic sires in bull beef production in New Zealand. Proceedings of the Tuapaka Exotic x Friesian Bull Beef Field Day, Massey University : 18-26.

Morris, S.T.; Inwood, P.R.; Parker, W.J. 1992. Intake, liveweight gain and grazing behaviour of exotic cross and Friesian bulls. Proceedings of the Tuapaka Exotic $x$ Friesian Bull Beef Field Day, Massey University : 9-13.

Morris, S.T.; Parker, W.J.; Purchas, R.W.; McCutcheon, S.N. 1991. Potential avenues for increasing income from sale of beef on dairy farms. Dairyfarming Annual 43 : 95-99.

Nicol, A.M. 1990. A simple drylsnd beef production system. Proceedings of the New Zealand Grassland Association 52 : 129-132.

Parker. W.J. 1991. Financial evaluation of once-bred heifer systems and their integration with the New Zealand beef industry. Proceedings of the Oncebred Heifer Field Day, Massey University : 8-22.

Purchas, R.W.; Morris, S.T.; Grant, D.A. 1992. A comparison of characteristics of the carcasses from Friesian. Piedmontese $\mathrm{x}$ Friesian and Belgian Blue $x$ Friesian bulls. New Zealand Journal of Agricultural Research (ii press). 